Short Communication

\title{
Performance Analysis of Direct Carbon Fuel Cell-Braysson Heat Engine Coupling System
}

\author{
Liwei Chen ${ }^{1,2},{ }^{*}$, Lihua Gao ${ }^{1}$, Yingyan Lin ${ }^{1}$ \\ ${ }^{1}$ School of Mechanical \& Electronic Engineering, Sanming University, Sanming 365004, China; \\ ${ }^{2}$ Department of Mechanical Engineering, University of South Carolina, Columbia, 29208, South \\ Carolina, USA. \\ *E-mail: $125601497 @$ qq.com
}

doi: $10.20964 / 2020.06 .32$

Received: 5 February 2020 / Accepted: 26 March 2020 / Published: 10 May 2020

In this paper, a new coupling system with irreversible Braysson based direct carbon fuel cell is constructed. The new irreversible coupling system can utilize the high quality waste heat generated in the working process of direct carbon fuel cell to drive the irreversible Braysson heat engine, so as to improve the overall working performance. The analytical expressions of direct carbon fuel cell, irreversible Braysson heat engine and coupling system are given respectively, and the performance of the newly constructed coupling system is obviously better than that of the single direct carbon fuel cell.

Keywords: irreversible Braysson heat engine; Direct carbon fuel cell coupling system; Performance analysis

\section{FULL TEXT}

(C) 2020 The Authors. Published by ESG (www.electrochemsci.org). This article is an open access article distributed under the terms and conditions of the Creative Commons Attribution license (http://creativecommons.org/licenses/by/4.0/). 